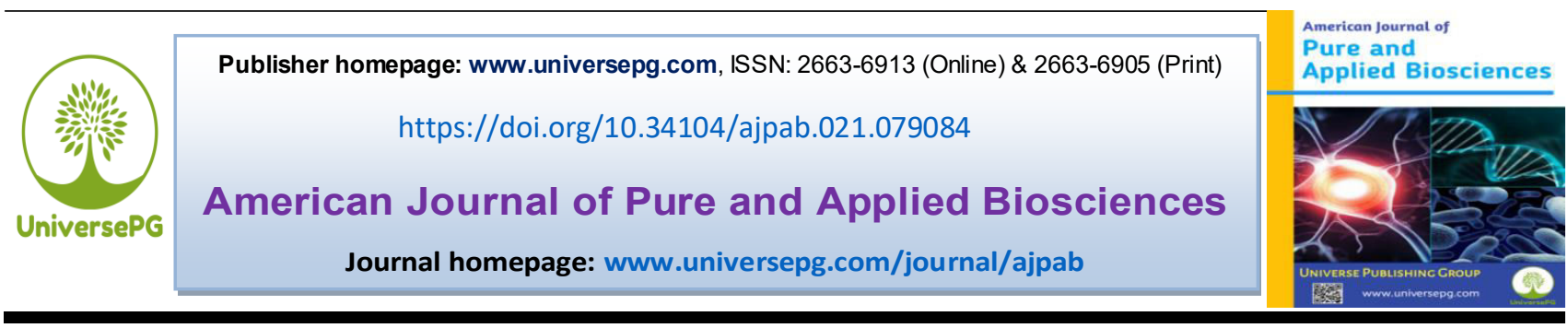

\title{
Scenario of Bangladesh in Various Sectors Due to Covid-19 Pandemic
}

\author{
Mehedi Hasan ${ }^{1}$, Md Nahid Ferdous ${ }^{1}$, Md. Aminul Islam ${ }^{1}$, Md. Rajib Hossain ${ }^{1 *}$, Md Sohanur Rahman', \\ Tanveer Ahmed ${ }^{3}$ and Md. Riajul Islam ${ }^{4}$
}

${ }^{1}$ Dept. of Environmental Science and Disaster Management, Bangabandhu Sheikh Mujibur Rahman Science and Technology University (BSMRSTU), Gopalganj-8100, Bangladesh; ${ }^{2}$ Dept. of Advanced Functional Materials, Technical University of Chemnitz, Chemnitz, Germany; ${ }^{3}$ Dept. of Petroleum and Mining Engineering, Jashore University of Science and Technology, Jashore-7408, Bangladesh; ${ }^{4}$ Dept. of Finance and Banking, Bangabandhu Sheikh Mujibur Rahman Science and Technology University (BSMRSTU), Gopalgonj-8100, Bangladesh.

*Correspondence: rajib.esd@bsmrstu.edu.bd (Md. Rajib Hossain, Assistant Professor, Dept. of Environmental Science and Disaster Management, BSMRSTU, Gopalganj-8100, Bangladesh).

\begin{abstract}
Coronavirus disease (COVID-19) has been declared pandemic by the World Health Organization on the 11th March 2020. COVID-19 has a wide range of effects. Increased Covid-19 infection is a major risk factor due to human unconsciousness and disobedience. The effects are increasing gradually. Therefore, the Bangladesh government has imposed a lockdown, but the outcome is adverse to this lockdown. It has shown us the real situation in our economic, social, education, service and health sectors. It reveals, in particular, that, as a result of Covid-19, our health sector, which is a basic human need, has entirely broken down, and that, as a result of the epidemic, our educational system has also been impacted. Generally speaking, the education sector will suffer significant damage. Our main purpose in this paper is to show the impact of Covid-19 on different sectors of our country.
\end{abstract}

Keywords: Covid-19, SARS-CoV-2, Pandemic, Impact, Scenario, Sectors and Bangladesh.

\section{INTRODUCTION:}

Coronavirus (COVID-19) is a contagious disease. It is caused by the coronavirus SARS-CoV-2, a part of the new virus family that typically causes lung sickness. Before the outbreak in Wuhan, China, in December 2019, it was unknown (Rahman et al., 2020; WHOc, 2020). This virus quickly spread thr-oughout different territories and, for this, it was dec-lared as a Public Health Crisis Worldwide Issue on January 30, 2020 by WHO (World Health Organization) (Rahman et al., 2020). COVID-19 was declared a pandemic by the WHO (World Health Organization) on March 11, 2020 (Chowdhury, 2020; Nahid, 2021, WHOd, 2020).

According to epidemiological surveys, the SARSCoV-2 virus has an incubation period of 1-14 days (Jin et al., 2020). The Institute of Epidemiology, Disease Control, and Research confirmed the first UniversePG I www.universepg.com
Corona virus patient in Bangladesh on March 8, 2020 (IEDCR, 2020). As Bangladesh is a densely populated country, it is probable that the novel corona virus will spread fast throughout the country (WHOa, 2020). Bangladesh will face a major challenge in controlling the newly emerging Corona virus outbreak (WHOb, 2020). Because there is no way to maintain social distance and no one is concerned about health issues (Barua, 2020; MPH, 2020). This study aims to find out the effect of Covid-19 on various sectors of Bangladesh.

\section{MATERIALS AND METHODS:}

The Covid-19 pandemic is still ongoing. It's difficult to find accurate and up-to-date information. This study is based on secondary data. We used credible newspapers, different study papers, and articles about this pandemic to gather data from the begi-nning of March 2020 to the beginning of June 2021. 


\section{Different impact of Covid-19 on Bangladesh}

Economy - The Covid-19 has already had an impact on a variety of industries. Firstly, the pandemic's initial impact is a temporary stoppage of factories and industries in the affected countries, resulting in decreased productivity (Barua, 2020). For example, many huge international corporations have already temporarily halted production in different countries (Whalen \& Bhattarai, 2020; Wilson, 2020). Bangladesh is being authorized to undergo lockdowns at various times and periods as confirmed cases of Covid-19 rise every day. The lockdown is having an effect on workers and companies around the country. The economy has completely halted. The real consequences may be seen in nearly every sector (Ahmed, 2020). Although major sectors receive special attention from authorities, the coronavirus pandemic had a significant impact on Bangladesh's major sectors, agriculture, industry, and services, which contributed 18\%, 29\%, and 53\% of the country's GDP, respectively (Bangladesh Econ. Rev., 2019; nath et al., 2020). Bangladesh's GDP is expected to drop by $\$ 3$ billion and more than $\$ 9$ million people will lose their jobs, according to the Asian Development Bank's ongoing Covid-19 pandemic (ADB, 2020).

Social - Covid-19 has had a negative impact on society in Bangladesh. The pandemic has also had an influence on religion, with several afflicted countries cancelling prayers in mosques, temples, and churches. Many churches and temples provide live streaming worship (Parke, 2020). Most Bangladeshis are Muslims, and rural religious authorities have started protesting the government's announcement and dri-ving thousands to cluster in mosques to pray for the virus's recovery. Bangladesh faces a threat from this massive gathering of religious people (Rafee, 2020). A large majority of individuals have lost their employment and livelihoods and they have been engaged in criminal offenses in this time period. According to the Bangladesh National Women Lawyers' Association (BNWLA), rape cases have increased dramatically in COVID-19. In January, 98 rapes occurred, followed by 92 in February, 67 in March, 76 in April, 94 in May, and 174 in June.

Education - The first Corona case was discovered on March 8. Educational institutions continued to operate. The Ministry of Primary and Secondary
Education is considering adopting distinct ways and habits of doing the do's and don'ts by the students and teachers. According to the education ministry, this was for the purpose of monitoring the situation (Alamgir, 2020b). Students from four different departments at Dhaka University quit classes on March 15 because of increasing Corona virus incidence (Alamgir, 2020a). The results of the S.S.C. and equivalent exams were sent out via text messages and posted on the Internet on May 31 (Dhaka Tribune, 2020). H.S.C exam has also been postponed because of this Covid-19 (HSC Exam 2020 Postponed Due to Coronavirus Fears in Bangladesh, 2020). Every day, students become more frustrated. Candidates for the H.S.C. have no idea when their exam will be held. Around them, distress is increasing. If the situation stays the same, the scenario of public universities will worsen (Alamgir, 2020c).

Although, private universities are continuing their classes online, they are encountering numerous issues. Many students have to face internet issue because it is not available in rural areas and making it impossible for continuing their studies through online. Students often say that learning thro-ugh online classes is tough. It's also challenging for teachers to teach because they're used to doing it in traditional ways (Islam, 2020). Now it has been more than one year, the educational institutes have closed. Covid-19 has a negative impact on our education system. Because, we have face numerous issues for completing the classes through online. Furthermore, many students suffer from various mental illnesses.

Service - As, governments of Bangladesh decided for long-term lockdown, a large number of individuals will lose their jobs. Several workers' rights organizations believe that a large number of people are already unemployed, with estimates ranging from 1.5 crore to upwards of 5 crore people, while two eco-nomists estimate that the figure will be between 1.30 crore and 1.50 crore people (Nath et al., 2020).

Tourism - Bangladesh has at least 12-15 international five-star hotels. Approximately 600 unknown three- and two-star hotels and motels are spread over Bangladesh. Bangladesh will lose more than Tk 3 billion in economic terms. More than half a million people employed in the tourist and hospitality industry, either directly or indirectly, are at risk of losing their jobs (Nath et al., 2020). 


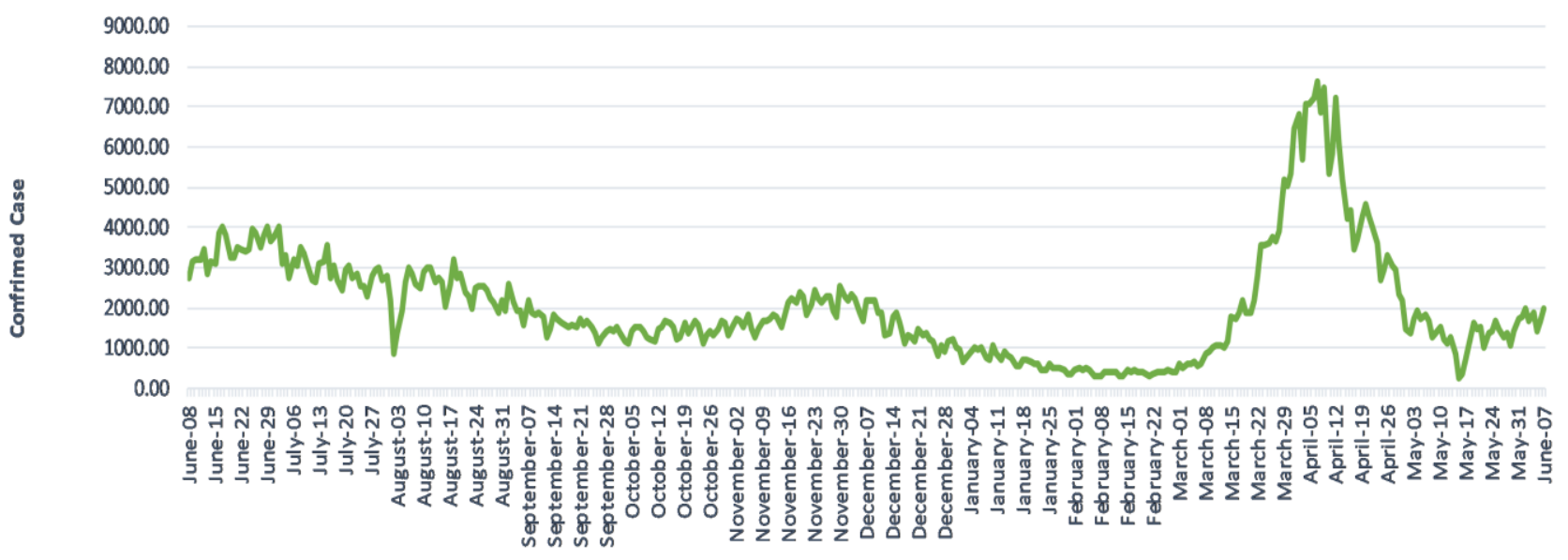

Date

Fig 1: Number of confirmed cases till June $7^{\text {th }}$ 2021(Coronavirus COVID-19 Dashboard, 2021).

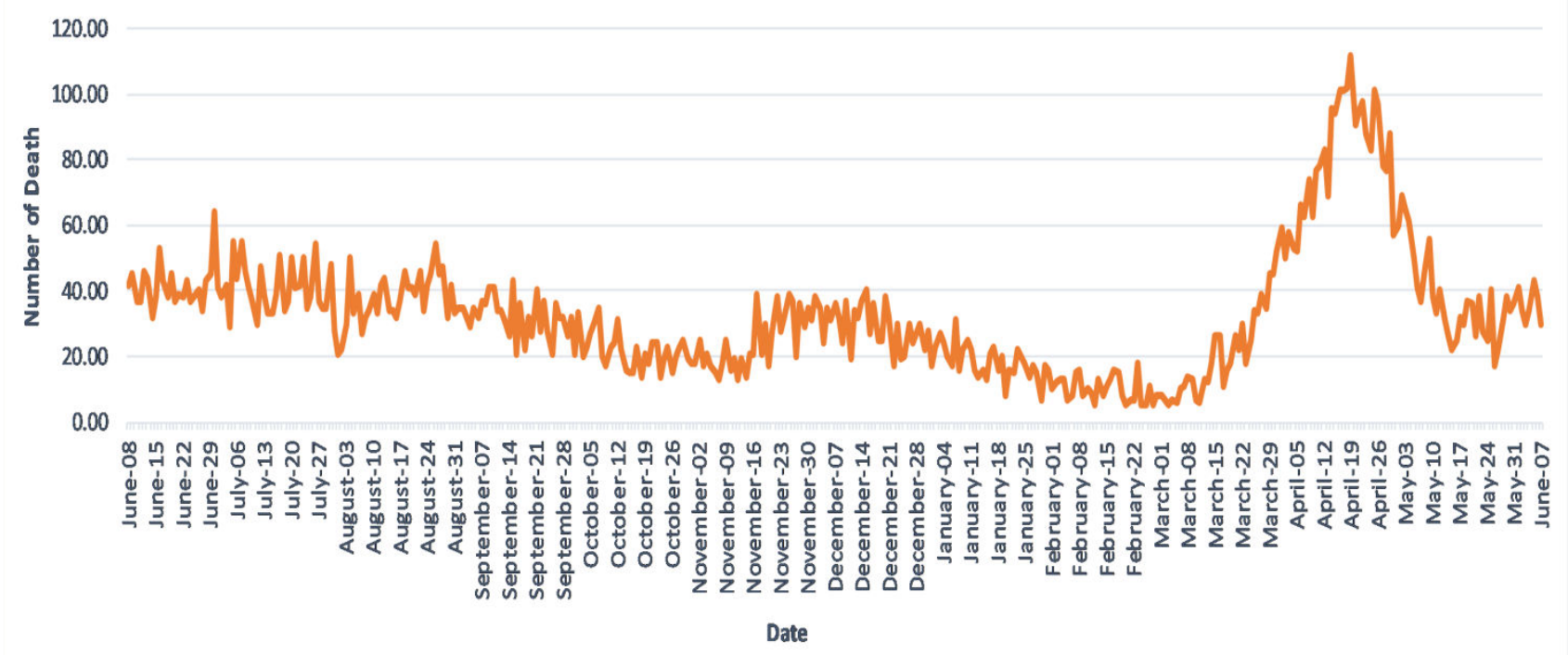

Fig 2: Number of deaths till June $7^{\text {th }}$ 2021(Coronavirus COVID-19 Dashboard, 2021).

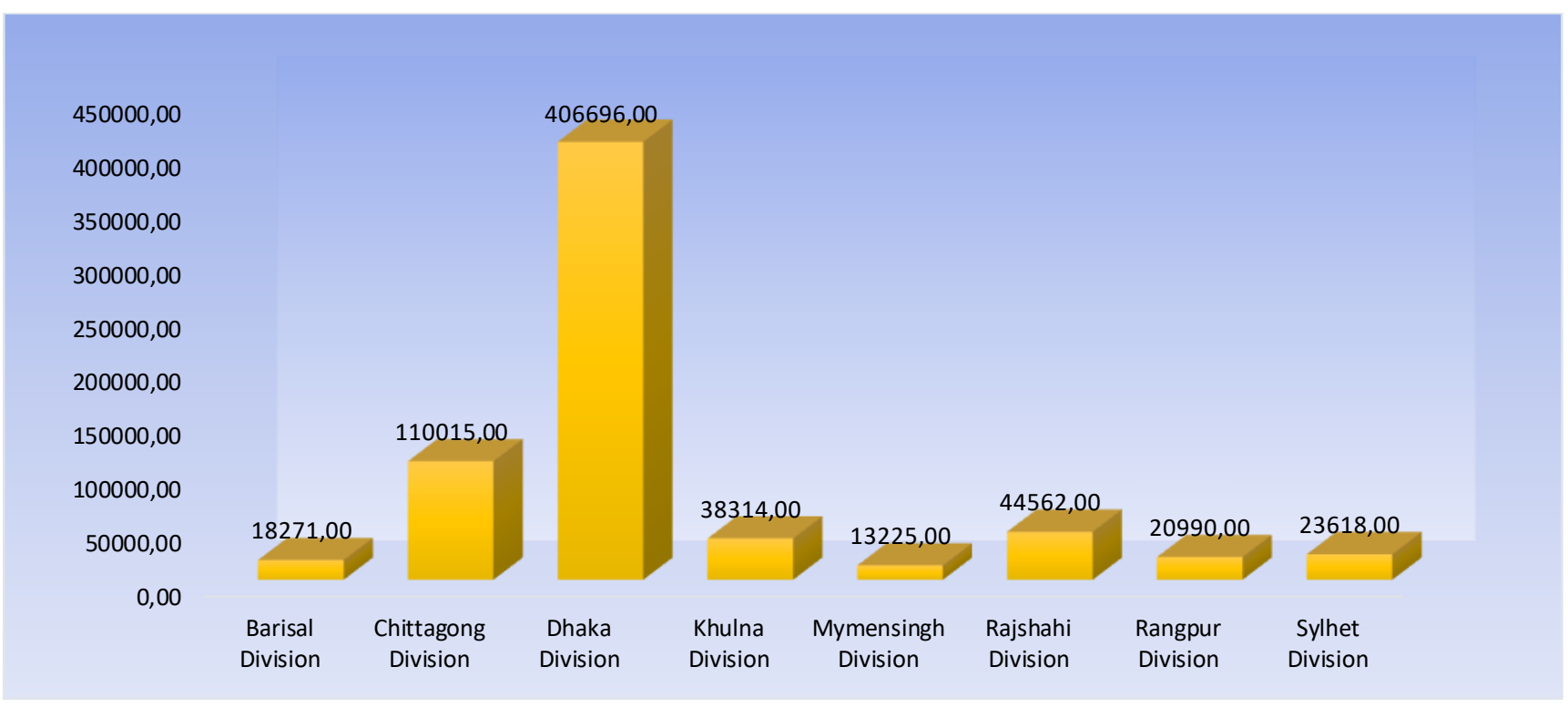

Fig 3: Number of confirmed cases according to Division (Coronavirus COVID-19 Dashboard, 2021). 


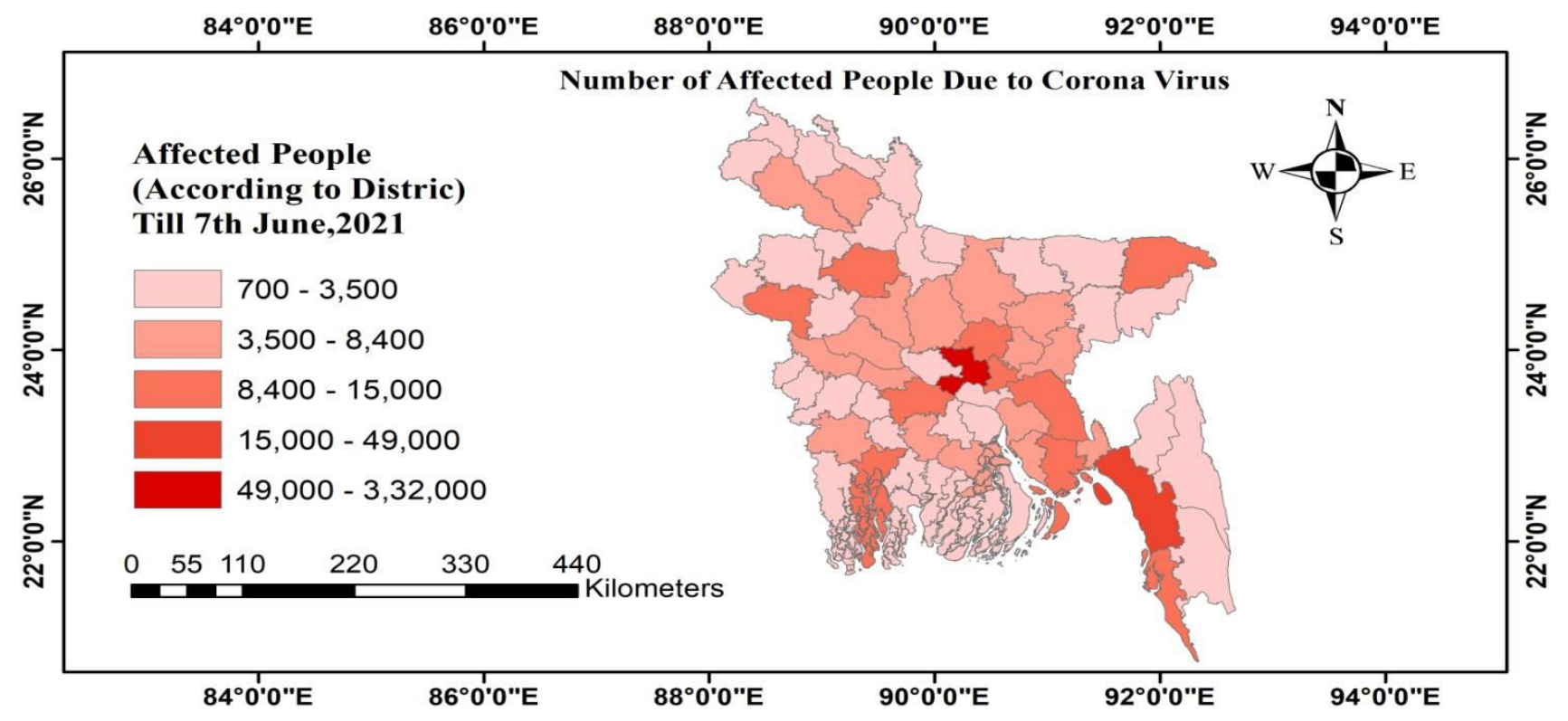

Fig 4: Affected people according to District till $7^{\text {th }}$ June 2021(Coronavirus COVID-19 Dashboard, 2021).

Health - On June 7, 2021, confirmed cases were 1970 (Fig 1), with 30 deaths (Fig 2). Fig 3 illustrates the number of confirmed cases according to division and the Dhaka division is in the first position. Fig 4 shows the number of affected people according to district and Dhaka district is also in first position among the districts. Up to the $7^{\text {th }}$ of June, 812,960 people had been infected, and 12,869 people had died. The death rate was approximately $1.6 \%$ (Coronavirus COVID-19 Dashboard, 2021). The maximum rate for testing is 17,169 which are, without a doubt, incredibly poor in comparison to our total population. We know that, medical facilities in Bangladesh are deplorable, particularly in government hospitals, and the Covid-19 situation exacerbates the situation. The real scenario is that Bangladesh does not have sufficient treatment for corona affected people and every day it is getting worse as the second wave of the corona virus is going on. The primary cause behind this is the lack of progress in the public health sector. The number of beds in total is $1,27,000$ in hospitals, with government hospitals accounting for 91,000 of them. Another problem is that these hospitals are situated in the capital (Dhaka) of Bangladesh. Last year, almost 1200 doctors from these hospitals died because of Covid19. This happened due to a lack of protective gear, PPE and masks, etc (Nath et al., 2020).

\section{DISCUSSION:}

Like other countries, different sectors of Bangladesh are distorted because of the Covid-19 pandemic. The economic system has been severely harmed as a result of this lockdown. The students have suffered greatly as a result of the pandemic. Students are unable to sit for exams or classes because educational institutions are closed. Online classes, on the other hand, are a solution to this problem, but they are not appropriate for all students. During the Covid-19 period, Bangladesh's health system was in shambles, and as a result, other sectors suffered as well.

\section{CONCLUSION:}

This pandemic is now becoming a threat for Bangladesh. This pandemic has caused a global social and economic crisis, and the infection is spreading at a rapid rate. So, the first step is to become aware of all of us as a group. We still donot know when the coronavirus's impact will diminish or when a vaccine for it will be developed. Until then, we must learn to cope with a new normal life. Obeying health rules and laws by the government such as wearing a mask, using hand sanitizer, not holding a public meeting in the same place, etc. to protect ourselves from this virus. The government and institutions should collaborate to provide university students with costeffective psychological care in a timely and accurate manner. Universities should establish all encompassing online-based educational programs to reach out to students living in remote places with or without access to the internet by offering scholarships or student loans. Authorities and policy maker of Bangladesh needs to take necessary steps so that different sector can make up their loss. Every people 
of Bangladesh get proper health care when they infected by covid- 19 .

\section{ACKNOWLEDGMENT:}

Authors of this paper acknowledging Md. Rajib Hossain, Assistant Professor, Dept. of Environmental Science and Disaster Management, Bangabandhu Sheikh Mujibur Rahman Science \& Technology University, Gopalganj-8100, Bangladesh for his valuable suggestions and time.

\section{CONFLICTS OF INTEREST:}

The authors declare that there is no conflict of interest regarding the publication of this paper.

\section{REFERENCES:}

1) $\mathrm{ADP},(2020)$. Coronavirus stands to wipe $\$ 3 \mathrm{~b}$ off Bangladesh economy | The Daily Star. (Asian Development Bank).

https://www.thedailystar.net/business/news/coro navirus-stands-wipe-3b-bangladesh-economy1877950

2) Ahmed H. U. (2020). Economic ramifications of Covid-19 in Bangladesh - Global Times. https://www.globaltimes.cn/content/1187977.sht $\underline{\mathrm{ml}}$

3) Alamgir M. (2020). Coaching centres open, defying govt directive | The Daily Star.

https://www.thedailystar.net/city/news/coachingcentres-open-defying-govt-directive-1882801

4) Alamgir M. (2020). Educational Institutions: Shutdown not in consideration yet | The Daily Star.

https://www.thedailystar.net/frontpage/news/edu cational-institutions-shutdown-not-considerati on-yet-1878151

5) Alamgir M. (2020). Public Universities: Session jams loom large $\mid$ The Daily Star.

https://www.thedailystar.net/frontpage/news/pub lic-universities-session-jams-loom-large-18958 $\underline{87}$

6) Bangladesh Economic Review (BER), (2019). Bangladesh Economic Review.

7) Barua, S. (2020). Understanding Coronanomics: The Economic Implications of the Coronavirus (COVID-19) Pandemic. SSRN Electronic Journal.

https://doi.org/10.2139/ssrn.3566477

8) Chowdhury, M. A. J. (2020). COVID-19 Pandemic and Bangladesh. Bangladesh Medical Research Council Bulletin, 46(1), 3-4. https://doi.org/10.3329/BMRCB.V46I1.47461
9) Coronavirus COVID-19 Dashboard, (2021). Retrieved June 15, 2021, from http://103.247.238.92/webportal/pages/covid19.p $\underline{\mathrm{hp}}$

10) Dhaka Tribune. (2020). $1,35,898$ students get GPA 5 in SSC exams | Dhaka Tribune.

https://www.dhakatribune.com/bangladesh/educa tion/2020/05/31/1-35-898-students-get-gpa-5-inssc-exams

11) HSC Exam 2020 postponed due to coronavirus fears in Bangladesh. (2020). The Daily Star. https://www.thedailystar.net/hsc-exam-2020-post poned-due-to-coronavirus-fears-in-bangladesh$\underline{1884304}$

12) IEDCR. (2020). Covid-19. IEDCR. https://www.iedcr.gov.bd/website/index.php/com ponent/content/article/73-ncov-2019

13) Islam S. (2020). Online education and reality in Bangladesh - Op-Ed - observerbd.com. The Daily Observer. https://www.observerbd.com/news.php?id=2561 02

14) Jin, Y. H., Cai, L., Cheng, Z. S., Cheng, H., Deng, T., Fan, Y. P., Fang, C., Huang, D., Huang, L. Q., Huang, Q., Han, Y., Hu, B., Hu, F., Li, B. H., Li, Y. R., Liang, K., Lin, L. K., Luo, L. S., Ma, J., Wang, X. H. (2020). A rapid advice guideline for the diagnosis and treatment of 2019 novel coronavirus (2019$\mathrm{nCoV}$ ) infected pneumonia (standard version). In Military Medical Research, BioMed Central Ltd. 7(1), 4. https://doi.org/10.1186/s40779-020-0233-6

15) MPH, D. I. H. (2020). The Epidemiological Characteristics of an Outbreak of 2019 Novel Coronavirus Diseases (COVID-19) In Bangladesh: A Descriptive Study. Journal of Medical Science And Clinical Research, 08(04). https://doi.org/10.18535/jmscr/v8i4.94

16) Nahid AHM. (2021). Resistance, unrest, protest and demonstration provoked by COVID19: a case study of Bangladesh, Asian J. Soc. Sci. Leg. Stud., 3(2), 23-34. https://doi.org/10.34104/ajssls.021.023034

17) Nath, J., Chowdhury, A. F., \& Nath, A. K. (2020). Analyzing COVID-19 Challenges in Bangladesh, Preprints 2020, 2020070129 https://doi.org/10.20944/PREPRINTS202007.01 29.V1

18) Parke, C. (2020). Churches cancel Sunday service, move online amid coronavirus outbreak. 


\section{Fox News.}

https://www.foxnews.com/us/coronavirus-upda te-church-sunday-service-online

19) Rafee A. A. (2020). The COVID-19 Outbreak: How Has Bangladesh Fared? Stimson Center. Stimson Center.

https://www.stimson.org/2020/the-covid-19-out break-how-has-bangladesh-fared/

20) Rahman, S. M. M., Hossain, S. M., \& Jahan, M. U. (2020). COVID-19 in Bangladesh: Measures for containment. In Bangladesh Medical Research Council Bulletin, Bangladesh Medical Research Council. 46(1), pp. 1-2.

https://doi.org/10.3329/bmrcb.v46i1.47460

21) Whalen J., \& Bhattarai A. (2020). China factory shutdown impact on U.S. businesses in wake of coronavirus outbreak - The Washington Post.

https://www.washingtonpost.com/business/2020/ 02/25/us-companies-so-far-are-surviving-chinasfactory-shutdown-next-few-weeks-are-crucial/

22) WHOa, (2020). Modes of transmission of virus causing COVID-19: implications for IPC precaution recommendations, World Health Organization (WHO).

https://www.who.int/news-room/commentaries/ detail/modes-of-transmiss ion-of-virus-causingcovid-19-implications-for-ipc-precaution-reco mmendations

23) WHOb, (2020). Our work in Bangladesh. World Health Organization (WHO). https://www.who.int/bangladesh/about-us/ourwork

24) WHOc, (2020). Q\&A on coronaviruses (COVID-19), World Health Organization (WHO). https://www.who.int/docs/default-source/searo/ bangladesh/2019-ncov/q-aen.pdf?sfvrsn=275ce $\underline{4 d 26}$

25) WHOd, (2020). WHO Director-General's opening remarks at the media briefing on COVID19 - 11 March 2020.

https://www.who.int/director-general/speeches/ detail/who-director-general-s-opening-remarksat-the-media-briefing-on-covid-19---11-march$\underline{2020}$

26) Wilson A. (2020). Coronavirus travel updates: which countries have restrictions and FCO warnings in place? | Travel | The Guardian. https://www.theguardian.com/travel/2020/mar/2 4/coronavirus-travel-updates-which-countrieshave-restrictions-and-fco-warnings-in-place 